\title{
Stylistyczne uwikłania artykułu poradnikowego (na przykladzie ogólnotematycznej prasy poradnikowej dla kobiet)
}

Dziennikarstwo poradnikowe należy do tych typów dziennikarstwa, które niezależnie od wieloletniej tradycji - w ostatniej dekadzie XX wieku rozwijały się w Polsce szczególnie intensywnie i od tego czasu zajmują stabilną i eksponowaną pozycję $\mathrm{w}$ ofercie medialnej. Jest odpowiedzią na silnie odczuwane przez odbiorców i w znacznym stopniu generowane kulturowo zapotrzebowanie na doradztwo'. Jego obecność zaznacza się we wszystkich trzech rodzajach poradnictwa zapośredniczonego wyróżnionych przez Darię Zielińską-Pękał, tj. poprzez media - wprost, poprzez media - obok i w poradnictwie ukrytym². Dzięki obecności nośnika oraz kierowaniu przekazu do masowego odbiorcy poradnictwo w ujęciu dziennikarskim nie ma ograniczeń przestrzennych i czasowych, zawarte w nim wskazówki zyskują bardziej uniwersalny charakter, możliwe staje się kreowanie fikcyjnej rzeczywistości (np. „list do redakcji” napisany przez dziennikarkę) generującej autentyczne przeżycia odbiorców związane z rozwiązywaniem problemu, a konkretne materiały poradnikowe mogą zyskiwać kolejne „wcielenia” w medium innym niż to, w którym pierwotnie powstały.

* Dr hab., e-mail: mowors@uni.lodz.pl; Uniwersytet Łódzki, Wydział Filologiczny, Katedra Dziennikarstwa i Komunikacji Społecznej; ul. Pomorska 171/173, 90-236 Łódź.

${ }^{1}$ Wśród czynników współdecydujących o takim zapotrzebowaniu należy wymienić m.in.: kształtowanie się kultury indywidualizmu i tzw. kultury instant, zastępowanie egalitaryzmu podejściem merytokratycznym, rozszerzanie się przestrzeni negocjacji (w tym w odniesieniu do systemów aksjologicznych), zachwianie stabilności tradycyjnych zadań i ról społecznych, a także więzi międzyludzkich, narastające poczucie tymczasowości i chwilowości oraz komplikacji i nieprzewidywalności życia przy jednoczesnej multiopcjonalności decyzji wyboru. Por. np. J. Kędzierska, Instruktorzy życia szczęśliwego. Fenomen współczesnych poradników - wybrane aspekty, „Global Media Journalism - Polish Edition” 2007, nr 1, s. 100-105, 99-116; Edukacja, wychowanie, poradnictwo w kulturze popularnej, red. M. Kondracka, A. Łysak, b.w., Wrocław 2009 (rozdział: Poradnictwo w kulturze popularnej, s. 88-142).

${ }^{2}$ Więcej zob. D. Zielińska-Pękał, Poradnictwo a świat mediów, czyli o poradnictwie zapośredniczonym, [w:] Poradoznawstwo - kontynuacja dyskursu. Podręcznik akademicki, red. nauk. A. Kargulowa, Wydawnictwo Naukowe PWN, Warszawa 2009, s. 285-307. 
Tak projektowane dziennikarstwo poradnikowe pełni rozmaite funkcje:

- wskazuje proste i skuteczne rozwiązania problemu (funkcja doradcza);

- kształci umiejętności konkretnego działania w określonej sytuacji (funkcja dydaktyczna);

- przekazuje wiedzę na dany temat (funkcja informacyjna);

- aktywizuje do samodzielnego działania w określonej sytuacji w przyszłości (modus działania) lub do wykształcenia określonego nawyku (funkcja aktywizująca);

- formułuje wskazówki, które uczynią życie odbiorcy lepszym, wygodniejszym, prostszym itd. (poprawianie jakości życia; funkcja modelująca);

- przyczynia się do budowania poczucia wspólnoty z osobami, które znalazły się w podobnej sytuacji i poradziły sobie oraz z tymi, które udzielają porad (funkcja integrująca);

- dopełnia porady określonym systemem wartości i wizją rzeczywistości zgodną z wizją autora publikacji (np. propagowanie wzorca kobiety zaradnej, energicznej, opiekuńczej, zorientowanej na tradycyjny model rodziny) (funkcja propagandowa);

- zaspokaja potrzeby zabawy, ciekawości, a nawet dramatyzmu i „,kibicowania swoim" (funkcja rozrywkowa).

W odniesieniu do prasy drukowanej dziennikarstwo poradnikowe jest ponadto modelowym przykładem wykorzystania nowoczesnych rozwiązań edytorskich, dzięki którym autorskie eksperymenty z formami przekazu pozwalają stale znajdować odbiorców dla w większości standardowej i cyklicznie powtarzalnej treści.

Prezentowane dalej wnioski opierają się na badaniach periodyków, zawierających niemal wyłącznie materiały poradnikowe uporządkowane $\mathrm{w}$ ramach powtarzalnej struktury ${ }^{3}$. Obejmuje ona kolejne działy tematyczne (moda/styl, uroda, zdrowie/medycyna, kulinaria, ludzie/rodzina/psychologia, dom/wnętrze, prawo, relaks), uzupełniane o nieliczne publikacje poświęcone znanym osobistościom, celebrytom, miejscom wartym zwiedzenia i tematom okazjonalnym (np. Walentynki). Zgodnie z obserwacjami Marii Wojtak i Ewy Bulisz, dotyczącymi prasy wyspecjalizowanej (w tym poradnikowej), również w badanym materiale zachodzi zjawisko redukcjonizmu genologicznego, które usuwa z pola widzenia czytelniczek takie formy tradycyjnego dziennikarstwa, jak komentarz, esej, artykuł publicystyczny czy felieton ${ }^{4}$. Wprowadza natomiast w ich miejsce

\footnotetext{
${ }^{3}$ Są to dwutygodniki i miesięczniki pozycjonowane jako poradnikowe, należące do liderów czytelnictwa w kategorii pism kobiecych na rynku polskim i wydawane przez czołowe koncerny wydawnicze (Burda Publishing Polska, Wydawnictwo Bauer, Edipresse Polska): „Claudia” (dalej w tekście: C), „Dobre Rady” (DR), „Kobieta i Życie” (KiŻ), „Naj” (N), „Olivia” (O), „Pani Domu” (PaD), „Poradnik Domowy” (PD), „Przyjaciółka” (P), „Świat Kobiety” (ŚK), „Tina” (T). Wysokość sprzedaży wydań drukowanych waha się między 120 tys. egz. (N) a 340 tys. egz. (KiŻ) (dane ZKDP za 2015 r.).

${ }^{4}$ Wyjątkiem wśród badanych pism jest „Poradnik Domowy”, w którym ukazuje się felieton Beaty Pawlikowskiej.
} 
daleko sięgające modyfikacje konwencji gatunkowych lub formy nowe, wielokształtne, znacząco poszerzające repertuar twórczych, oryginalnych rozwiązań dostosowanych do nieszablonowego layoutu ${ }^{5}$. Dzięki temu pismo zyskuje niezwykle atrakcyjną wizualnie szatę graficzną, niemonotonną, a zarazem przejrzystą i uporządkowaną, która zachęca do zapoznania się z tekstem i ułatwia jego percepcję. Zarazem jednak taki przekaz staje się wyzwaniem dla badacza, wymykając się tradycyjnym klasyfikacjom i opisom genologicznym oraz wzbogacając kategorię „okazów”.

W analizowanych numerach czasopism z pierwszego kwartału 2016 roku można wskazać kilkanaście schematów gatunkowych, różnorodnie realizowanych. Od tradycyjnej miniporady w kształcie sygnału czy porady eksperta stowarzyszonej $z$ listem lub jego fragmentem, poprzez metamorfozy $i$ autodiagnostyczne testy, do wielogatunkowego raportu i rozbudowanego kolażu?. Chcąc możliwie precyzyjnie uchwycić ich stylistyczne zróżnicowanie, warto skoncentrować uwagę na formie o dużym stopniu reprezentatywności w materiale badawczym, a zarazem niejednorodności w obrębie typu - na artykule poradnikowym. W moim przekonaniu najwyraźniej odzwierciedla on tendencje stylistyczne właściwe współczesnej prasie poradnikowej dla kobiet, co wynika z jego strukturalnego nieustabilizowania i dynamiki charakteryzującej autorską intencjonalność rozpoznawalną w tekście.

Ewa Ficek trafnie dostrzega trudności opisu skomplikowanej formy artykułu poradnikowego, sytuując ich źródło w genetycznym związku z artykułem gatunkiem o nieprecyzyjnie ustalonych cechach typologicznych ${ }^{8}$. O ile jednak podbudowa naukowa, walor dydaktyczny oraz przystępny język pozostają niekwestionowanymi wyznacznikami jego poradnikowej odmiany, to już spójna, trójczłonowa budowa (teza/hipoteza - argumenty/analiza - podsumowanie/konkluzje) stanowi raczej rozwiązanie wyjątkowe. Znacząco częściej autorzy korzystają z innych zasad porządkowania wywodu.

${ }^{5}$ Zob. M. Wojtak, Kunszt stylizatorski w artykułach z prasy wyspecjalizowanej, [w:] taż, Roztożone gazety. Studia z zakresu prasowego dyskursu, języka i stylu, Wydawnictwo UMCS, Lublin 2015, s. 81-93; E. Bulisz, Redukcjonizm genologiczny we współczesnej prasie poradnikowej dla kobiet, ,Stylistyka” 2014, t. 23, s. 397-414.

${ }^{6}$ Według określenia M. Wojtak - zob. taż, Gatunki prasowe, Wydawnictwo UMCS, Lublin 2004, s. 309; Por. M. Worsowicz, Nowatorstwo tekstów poradnikowych (wybrane przyktady prasowe), „Acta Universitatis Lodziensis. Folia Litteraria Polonica” 2013, t. 13, s. 405-413.

${ }^{7}$ Por. E. Ficek, Formy (i dzisiejsze normy) poradnictwa prasowego - analiza genologiczna, [w:] Gatunki mowy i ich ewolucja, t. 5: Gatunek a granice, red. D. Ostaszewska, J. Przyklenk, Wydawnictwo UŚ, Katowice 2015, s. 230-237; M. Wojtak, Osobliwe byty gatunkowe i tekstowe wich uwiktaniach komunikacyjnych, [w:] Gatunki mowy i ich ewolucja, t. 4: Gatunek a komunikacja społeczna, red. D. Ostaszewska przy współudziale J. Przyklenk, Wydawnictwo UŚ, Katowice 2011, s. 47-49, 44-56.

${ }^{8}$ Zob. E. Ficek, dz. cyt., s. 234; K. Wolny-Zmorzyński, A. Kaliszewski, W. Furman, Gatunki dziennikarskie. Teoria, praktyka, język, Wydawnictwa Akademickie i Profesjonalne, Warszawa 2006, s. 85-86. 
Mając na uwadze powyższe zastrzeżenia, przyjmuję, że artykułem poradnikowym jest 1-3-kolumnowa publikacja obejmująca tekst zasadniczy (złożony z nagłówka, lidu oraz wieloakapitowego, spójnego korpusu), obudowany elementami dodatkowymi (ramki, miniporady ${ }^{9}$, tabele, rekomendacje ${ }^{10}$ itp.) oraz grafiką (zdjęcia, rysunki, infografiki itp.). Autor - dziennikarz wspierający się konsultacją eksperta bądź sam ekspert - koncentruje się na temacie-problemie, w swoim wywodzie łącząc diagnozę z zaleceniami i zachętami, niekiedy wyróżnionymi w obrębie korpusu w postaci listy. W tekście dominuje intencja doradzania wskazania możliwie najkorzystniejszej w danej sytuacji drogi postępowania, ale widoczna jest również chęć okazania zrozumienia i empatii tym, którzy już borykają się z opisywanym problemem lub natkną się na niego w przyszłości ${ }^{11}$. Ze względu na dużą objętość publikacja jest dzielona na części śródtytułami, których rolę odrywać mogą także krótkie pytania - w takim przypadku kolejne części tekstu zawierają kilkuzdaniowe odpowiedzi, a tekst adaptuje formułę wywiadu (np. PD, 2, 31) ${ }^{12}$. Najczęstszy wzorzec alternacyjny artykułu poradnikowego opiera się na jeszcze wyraźniejszym rozczłonkowaniu korpusu - na poprzedzone wprowadzeniem minimum dwie części o analogicznej budowie, w których mogą zostać wyodrębnione kolejne segmenty o precyzyjnie wskazanej funkcji (np. komentarz eksperta + opis zabiegu kosmetycznego; opis zabiegu, który można wykonać w domu i zabiegu w gabinecie kosmetycznym + rada specjalisty + rekomendacje, np. PD, 2, 22-25; PD, 3, 24-26).

Szczegółowe omówienie stylistyki nagłówków oraz lidów artykułów poradnikowych wymaga odrębnego opracowania; w niniejszym artykule skoncentruję się na zasadniczej treści ujętej w korpusach publikacji.

Pod względem stylistycznym najlepiej dopracowane są początkowe partie tekstów. Autorzy starają się zaciekawić czytelniczki tematem, unaoczniając im problematyczną sytuację, a jednocześnie starając się wywołać zaangażowanie w lekturę poprzez podkreślanie wagi i/lub powszechności opisywanego zjawiska.

9 Jest to rodzaj graficznie wyróżnionych na kolumnie „wklejek tekstowych” (określenie E. Ficek), zawierających bardzo krótką poradę-wskazówkę, tematycznie związaną z zasadniczym tekstem. Por. E. Ficek, dz. cyt., s. 232.

${ }^{10}$ Nazywam tak publikację złożoną z nagłówka, zdjęcia i komunikatu perswazyjnego w postaci zachęty lub wskazówki oraz składnika informacyjnego (metki), odnoszącego się do konkretnego produktu i zawierającego dane na temat jego nazwy, producenta lub miejsca, w którym jest dostępny, oraz ceny. Rekomendacje występują najczęściej w zbiorach (wówczas może nastąpić redukcja struktury do metki lub zachęty i metki), mogą stanowić publikację autonomiczną lub być składnikiem kolekcji gatunków o wspólnym temacie, albo dopełniać samodzielny tekst informacyjny lub poradnikowy.

11 To zastrzeżenie wyłącza z obszaru analiz teksty o funkcji doradczo-rekomendującej poświęcone miejscom wartym zobaczenia i zwiedzenia, również obecnym w prasie poradnikowej (np. J. Kochańska, Chetmno miejsce spotkań zakochanych, „Poradnik Domowy” 2016, nr 3, s. 108-109).

${ }^{12}$ Lokalizując egzemplifikacje, podaję w nawiasie skrót nazwy czasopisma, jego numer, numer strony. 
W tym celu wykorzystują np. konwencję opowieści reporterskiej, wyobrażenie przyszłości lub opis mający wywołać uczucia niepokoju czy nawet lęku:

Kilka tygodni temu Katarzyna otrzymała zaproszenie na drugie urodziny synka swojej przyjaciółki. [...] Była zaskoczona, gdy [...] usłyszała, że rodzice sprezentowali Jankowi tablet. [...] Włączona natychmiast gra tak pochłonęła jubilata, że ledwo udało się go namówić do zdmuchnięcia świeczek na torcie. Z ciocią Kasią nie zamienił nawet słowa... Myślisz, że to odosobniony przypadek? Niestety, nie! Coraz częściej zdarza się, że smartfon czy tablet „umila” czas roczniakowi na spacerze w wózku czy „ułatwia” zasypianie [...]. Z czasem telefon i tablet wypierają zwykłe zabawki, książki i typowo dziecięce rozrywki [PD, 3, 94].

Wyobraź sobie swojego syna za dwadzieścia lat. Jest odpowiedzialnym mężem i ojcem, który nie wstydzi się emocji. Chciałabyś też, żeby twoja córka miała poczucie własnej wartości i umiała o siebie zadbać. Choć są jeszcze mali, już możesz przygotować ich na różne wyzwania $[\mathrm{O}, 2,73]$.

Twój dom, a szczególnie sypialnia i tapicerowane meble w salonie, jest oblegany przez roztocze kurzu domowego [...]. W przeciętnym mieszkaniu żyje ich 2 miliony! Gdybyś obejrzała pod mikroskopem materac ze swojego łóżka, poduszkę czy ukochaną przytulankę byłabyś pod wrażeniem [P, 2, 22].

Na podobny efekt zaangażowania mogą liczyć autorki publikacji rozpoczynających się od cytatu listu do redakcji lub opisu konkretnego przypadku (np. P, 3, 42; DR, 3, 78) - nawet jeśli jego wiarygodność jest wątpliwa (choć dla jej podtrzymania wykorzystuje się stylizację na potoczność i/lub intymność i pseudocytaty), eksponuje personalny sposób ujęcia tematu, a tekst zyskuje walor skutecznej (jak może przypuszczać czytelniczka) interwencji dziennikarskiej.

Standardowy początek artykułu poradnikowego to połączenie wprowadzającej w temat konstatacji, zanęta sygnalizująca, że warto się nim zainteresować i/bądź zachęta lub polecenie zapoznania się z publikacją (np. PaD, 3, 18). Rzadko autorzy już we wstępie formułują określone żądania wobec czytelniczek (np. ŚK, 2, 40).

Plastyczne i przemawiające do wyobraźni wprowadzenie silnie kontrastuje ze stylem wypowiedzi informacyjnych, nasyconych nazwami i danymi liczbowymi, oraz popularnonaukowych, zachowujących - choć w ograniczonym stopniu - precyzję i fachowość wykładu naukowego ${ }^{13}$. Takie zaś nacechowanie często można zaobserwować we fragmentach następujących po wprowadzeniu. Stwarzają one niezbędny kontekst - diagnoza problemu zyskuje walor profesjonalizmu i wiarygodności - a zarazem przygotowują czytelniczki do zaakceptowania pouczeń, formułowanych w tonie bardziej dyrektywnym.

${ }^{13}$ Zob. J. Obara, Stownictwo nieoficjalne w poradach medycznych kolorowych czasopism dla kobiet, [w:] Dobra rada nie zawada. Rady, porady i poradniki w języku, literaturze i kulturze, red. W. Żarski, B. Staniów, Państwowa Wyższa Szkoła Zawodowa w Koszalinie, Koszalin 2010, s. 80, 79-91. 
Innym sposobem wzbudzenia zainteresowania publikacją jest uświadamianie czytelniczkom błędnych przekonań, jakie dotychczas żywiły na dany temat, lub tłumaczenie, iż uległy manipulacji (np. PD, 2, 82). Zderzenie fałszu i prawdy rozpoczyna argumentację opartą na precyzyjnym opisie trudności lub zagrożeń, który sprzyja wywołaniu poczucia bezradności oraz niepewności. Te zaś redukowane są z pomocą sformułowań opartych na rozkaźnikach oraz orzeczeniach modalnych zawierających leksemy, takie jak: musieć, należy, trzeba, powinno się. Zachęta i sugestie możliwości dokonywania wyboru, czyli posługiwanie się słowami typu: lepiej (+ nazwa alternatywnej czynności), warto, można, występują rzadziej.

W badanych tekstach ujawniła się wyraźna tendencja harmonizowania stylu udzielania porad z konstrukcją publikacji. Te, których korpus wypełnia raczej jednorodny, autorski wywód, o słabiej eksponowanej modularności treściowej, zawierają sygnały przyjaznej postawy autora, który chce udzielić rzeczowej informacji, być pomocnym partnerem, proponować rozwiązania korzystne i łatwe do wdrożenia przez czytelnika. Ten ,spolegliwy opiekun"14 sygnalizuje, że rozumie trudną sytuację i rozterki osoby, którą ona dotknęła (np. O, 3, 132-133). Stawiane przez niego pytania to $\mathrm{w}$ istocie ,głośne myślenie” samej czytelniczki, a udzielane odpowiedzi (także przez ekspertów, którym oddaje się głos) ujawniają różne możliwe rozwiązania, a niekiedy kolejne etapy na drodze do wyeliminowania problemu. „Wyrozumiałość” autora nie sprawia jednak wrażenia okazywania tolerancji dla przejawów infantylizmu, co z pewnością byłoby obraźliwe dla adresatek, ma bowiem uzasadnienie w obiektywnych warunkach - tradycji, kulturze, warunkach współczesnego życia:

Nie zastanawiamy się nad tym, co jest dla nas dobre, lecz usiłujemy jak najlepiej wykonywać swoje obowiązki, a to generuje stres. Celują w tym szczególnie kobiety. [...] Efektywnego relaksu należy się nauczyć. Sęk w tym, że mamy na tej płaszczyźnie spore zaległości... [PD, 3, 87].

Wrażenie podmiotowego podejścia do czytelniczek wzmacnia nieco rzadsze niż w typowych materiałach poradnikowych stosowanie wspomnianych orzeczeń modalnych - są one zastępowane zwykłymi czasownikami w formie 1 osoby 1.mn. czasu teraźniejszego, niekonotującymi przymusu, lecz wprowadzającymi do przekazu wymiar wspólnotowy:

Możemy się do niej [instytucji Rzecznika Finansowego] zwrócić w każdej sytuacji, w której uważamy, że firma ubezpieczeniowa potraktowała nas nieuczciwie [...].

\footnotetext{
${ }^{14}$ Por. B. Wojtasik, Doradca zawodu. Studium teoretyczne z zakresu poradoznawstwa, Wydawnictwo UWr, Wrocław 1993, s. 60.
} 
W skardze do rzecznika dokładnie opisujemy sprawę i dołączamy kopie dokumentów $[\ldots][\mathrm{O}, 3,133]$.

Eksponowanie partnerskiej relacji autor - czytelniczki nie wyklucza jednak stosowania środka o silnie dyrektywnej w tym kontekście intencji: asercji. Usuwają one z pola widzenia adresatek porad alternatywę dla działań opisywanych w tekście, ale zarazem upodabniają wypowiedź do repliki empatycznego rozmówcy:

Wielu rodzicom wydaje się, że męska odpowiedzialność polega głównie na zarabianiu pieniędzy. [...] Ale ty chcesz, żeby on [syn] nie troszczył się jedynie o materialne sprawy. Zależy ci, żeby obchodziło go również to, co czują jego bliscy. I żeby sam umiał wyrażać emocje [O, 2, 75].

Artykuły z cząstkowymi adaptacjami rejestru (listy lub wyliczenia) także mogą wykorzystywać konwencje reportażowe, jednak sytuacje, będące punktem wyjścia w kolejnych poradnikowych częściach, mają wymowę uniwersalną - opisują schemat, do którego można dopasować wiele indywidualnych przypadków (np. KiŻ, 2, 82-83). Dla tego celu autorzy wykorzystują pseudocytaty, mowę zależną i pozornie zależną, mieszają fakty z ich interpretacjami.

W tej grupie tekstów poradnikowych częściej pojawiają się krótkie wytyczne, ukierunkowane przedmiotowo i praktycznie, przypominające instrukcję:

Temperatura. Pokój nie powinien być przegrzany. Na noc warto zmniejszyć temperaturę do ok. 18 st. C. Gdy nie ma dużego mrozu, można je [storczyki] postawić przy rozszczelnionym lub uchylonym oknie. [...]

Kurz na liściach. Wycieraj go miękką ściereczką. Unikaj przestawiania rośliny [PaD, 2, 44-45].

Równie silny nacisk na czytelniczki mogą wywrzeć formy 1 osoby 1.mn. czasowników (np. nie pozwólmy, by..., powiedzmy wtedy, że...), gdyż dydaktyczne „my” wspiera w nich funkcję rozkaźników i służy przekonaniu, że jest tak (lub powinno być), jak twierdzi autor.

Subtelniejszą perswazją wyróżniają się krótkie opisy korzystnego działania i jego efektów, jakie czytelniczka łatwo może odnieść do własnej sytuacji; mogą być one uwiarygodniane powołaniem się na źródła naukowe, co stylowi informacji dodaje waloru profesjonalizmu:

To [uprawianie seksu] idealna gimnastyka dla układu oddechowego, bo powoduje głęboką wentylację płuc. Organizm doznaje niemal szoku tlenowego, jak w czasie godzinnego spaceru. A gdy wraz z krwią więcej tlenu dociera np. do mózgu, sprawniej potem myślimy [PD, 3, 57]. 
Wymiar poznawczy omawianego typu artykułu odgrywa bardzo istotną rolę w budowaniu jego poradnikowego charakteru, ponieważ zachęty i polecenia odwołują się przede wszystkim do racjonalnego bilansowania zysków i strat, do rozumienia procesów oraz związków przyczynowo-skutkowych, w mniejszym natomiast stopniu do reakcji emocjonalnych. Można dostrzec wyraźną zależność - w tekstach poświęconych stylowi życia, zdrowiu, sprawom rodzinnym i pracy dominuje perswazja racjonalna, wymagająca właściwego dekodowania np. nazw własnych, danych statystycznych, specjalistycznej leksyki, śledzenia indukcji, sylogizmów i entymematów, natomiast prasowe poradnictwo w zakresie mody i urody częściej opiera się na estetycznych i afektywnych zestawieniach, porównaniach i skojarzeniach. W pierwszym przypadku najważniejszą i ostateczną „instancją” poradniczą pozostaje ekspert - stąd tak częste, szczególnie w tekstach na temat zdrowia, zalecenia, aby skonsultować się z fachowcem lub poddać badaniu. W drugim natomiast - kryteriami rozstrzygającymi są aktualny trend i stosowność w danej sytuacji (np. styl makijażu dobrany do okazji).

Stylistyka artykułów poradnikowych w ogólnotematycznej prasie poradnikowej dla kobiet nie jest wyszukana i z pewnością nie stanowi najważniejszego czynnika decydującego o przyjemności lektury. Można też zauważyć, że w tytułach z „niższej półki” („Dobre Rady”, „Naj”, „Pani Domu”, „Tina”) gatunek ten zazwyczaj występuje we wzorcach alternacyjnych z korpusem modułowym, wykorzystującym formułę rejestru. Są to teksty mniejsze objętościowo i składniowo prostsze (krótkie zdania, zwykle pojedyncze lub jednokrotnie złożone), z częstym użyciem zestawień pytanie - odpowiedź, wykrzyknień sygnalizujących emocje, a także wyliczeń. Doradzanie oparte jest głównie na bezpośrednich, konkretnych wskazówkach, ujętych w dyrektywnym stylu, odpowiednim dla parenetycznej wymowy publikacji.

Redakcje pism takich, jak „Olivia” czy „Świat Kobiety” silniej akcentują profesjonalizm swojego poradnictwa. Autorzy wyraźnie ujawniają intencję nawiązania bardziej przyjacielskiego kontaktu z czytelniczkami (orientacja dialogowa), ale jednocześnie skłaniają je do uważniejszego śledzenia toku wywodu i wysiłku intelektualnego. W tekstach pojawia się bardziej zróżnicowana składnia, więcej urozmaiconych środków stylistycznych, sygnałów dialogowości; lepiej harmonizowana jest warstwa faktograficzno-poznawcza publikacji z ich funkcją użytkową.

Omówiony gatunek jest jedną z wielu form wypowiedzi praktykowanych w badanych pismach. Jego ukształtowanie, tak pod względem stylistycznym, jak i strukturalnym, pozwala autorom wyzyskiwać wszelkie możliwości od- 
działywania perswazyjnego typowego dla czasopism poradnikowych. Można zatem przypuszczać, że jego dalsza ewolucja będzie postępować wraz z pojawianiem się nowych sposobów modelowania formuły i zawartości tego segmentu prasy.

\section{Bibliografia}

Bulisz E., Redukcjonizm genologiczny we współczesnej prasie poradnikowej dla kobiet, „Stylistyka" 2014, t. 23, s. 397-414.

Edukacja, wychowanie, poradnictwo w kulturze popularnej, red. M. Kondracka, A. Łysak, b.w., Wrocław 2009.

Ficek E., Formy (i dzisiejsze normy) poradnictwa prasowego - analiza genologiczna, [w:] Gatunki mowy i ich ewolucja, t. 5: Gatunek a granice, red. D. Ostaszewska, J. Przyklenk, Wydawnictwo UŚ, Katowice 2015, s. 230-237.

Kędzierska J., Instruktorzy życia szczęśliwego. Fenomen współczesnych poradników - wybrane aspekty, „Global Media Journalism - Polish Edition” 2007, nr 1, s. 99-116.

Kochańska J., Chetmno miejsce spotkań zakochanych, „Poradnik Domowy” 2016, nr 3, s. 108-109.

Obara J., Stownictwo nieoficjalne w poradach medycznych kolorowych czasopism dla kobiet, [w:] Dobra rada nie zawada. Rady, porady i poradniki w języku, literaturze i kulturze, red. W. Żarski, B. Staniów, Państwowa Wyższa Szkoła Zawodowa w Koszalinie, Koszalin 2010, s. 79-91.

Wojtak M., Gatunki prasowe, Wydawnictwo UMCS, Lublin 2004.

Wojtak M., Kunszt stylizatorski w artykułach z prasy wyspecjalizowanej, [w:] taż, Rozłożone gazety. Studia z zakresu prasowego dyskursu, języka i stylu, Wydawnictwo UMCS, Lublin 2015, s. 81-93.

Wojtak M., Osobliwe byty gatunkowe i tekstowe w ich uwikłaniach komunikacyjnych, [w:] Gatunki mowy i ich ewolucja, t. 4: Gatunek a komunikacja spoleczna, red. D. Ostaszewska przy współudziale J. Przyklenk, Wydawnictwo UŚ, Katowice 2011, s. 44-56.

Wojtasik B., Doradca zawodu. Studium teoretyczne z zakresu poradoznawstwa, Wydawnictwo UWr, Wrocław 1993.

Wolny-Zmorzyński K., Kaliszewski A., Furman W., Gatunki dziennikarskie. Teoria, praktyka, język, Wydawnictwa Akademickie i Profesjonalne, Warszawa 2006.

Worsowicz M., Nowatorstwo tekstów poradnikowych (wybrane przyktady prasowe), „Acta Universitatis Lodziensis. Folia Litteraria Polonica" 2013, t. 13, s. 405-413.

Zielińska-Pękał D., Poradnictwo a świat mediów, czyli o poradnictwie zapośredniczonym, [w:] Poradoznawstwo - kontynuacja dyskursu. Podręcznik akademicki, red. nauk. A. Kargulowa, Wydawnictwo Naukowe PWN, Warszawa 2009, s. 285-307. 
Monika Worsowicz

\section{The stylistic conditioning of an advice-type article (based on general lifestyle press aimed at women)}

\section{(Summary)}

The advice article is one of the multiple forms of expression in use among general lifestyle magazines aimed at women. Its shape, both style and structure-wise, allows authors to exhaust all the possibilities of persuasive action, which is typical for this group of magazines. The analysis of the materials, taken from ten separate magazines published in the first quarter of 2016, shows that the stylistic range of advice articles is not sophisticated, and so their style is definitely not the most important factor which determines the pleasure of reading. It is also possible to notice that in the down-market magazines ('Dobre Rady', 'Naj', 'Pani Domu', 'Tina') this type of an article is usually produced in a form of a corpus (body) made of modules, using the formula of a register. These texts are smaller in size and compositionally more simple (short sentences, usually single sentences or simple relative clauses), with regular use of a question-answer configuration, with exclamations to show emotions, and lists. The act of giving advice is generally based on direct, specific instructions, formulated in a direct style, appropriate for the 'parenetic' (persuasive) character of the publication. The editorial boards of magazines such as 'Olivia' or 'Swiat Kobiety' heavily emphasize the professionalism of their guidance. The authors clearly display their intent to create a more friendly relationship with their female readers, but at the same time encourage them to follow the line of argument more carefully and to think for themselves. In these texts the syntax is more complex, more varied rhetorical terms are used, and the signals of mutual dialogue are present; the factual, graphic and cognitive layer of a publication blends with its practical usage in a much better way.

Keywords: lifestyle press, advice-type article, stylistics. 